\title{
Secondary fluorescent staining of virus antigens by rheumatoid factor and fluorescein-conjugated anti-IgM
}

\author{
P. V. SHIRODARIA, K. B. FRASER, AND F. STANFORD \\ From the Department of Microbiology, the Queen's University of Belfast, and the Royal Victoria \\ Hospital, Belfast, Northern Ireland
}

Human sera appear not to contain virus-specific IgM when unassociated with recent virus infection (Baublis and Brown, 1968; Connolly, Haire, and Hadden, 1971; Haire and Hadden, 1970; Schluederberg, 1965). Indeed, two studies using fluorescent antibody suggest that virus-specific IgM may be, exceptionally, an indicator of persistent infection (Connolly and others, 1971; Haire and Hadden, 1970). When we applied the fluorescent antibody method to search for virus-specific IgM in sera from rheumatoid arthritis, individual sera from patients with that disease appeared to contain IgM reacting with several different viruses. This anomaly and some simple experiments designed to explain it are described here.

\section{Methods}

HUMAN SERA

Sera were inactivated by heating at $60^{\circ} \mathrm{C}$. for $30 \mathrm{~min}$. then stored at minus $20^{\circ} \mathrm{C}$. Some were inactivated after being stored unheated. Four rheumatoid sera containing rheumatoid factor were taken from patients aged between 40 years and 60 years, and a number of paired acute and convalescent sera from measles, mumps, rubella, and herpes simplex were taken at widely different ages (see Table I).

\section{RHEUMATOID FACTOR (RF)}

Here we refer to factor tested for by the latex slide agglutination test (Hyland's RA test). Semi-purified factor was prepared by absorption on aggregated human gamma globulin and elution with glycine-saline buffer at pH 3.5. The agglutinating titre, after dialysis to $\mathrm{pH} 7 \cdot 2$, was $1: 10$.

Accepted for publication March 24, 1972
ABSORPTION WITH AGGREGATED GAMMA GLOBULIN Cohn fraction II human gamma globulin was aggregated by heating to $73^{\circ} \mathrm{C}$. for $10 \mathrm{~min}$. at $\mathrm{pH} 7 \cdot 2$. Sera were first absorbed with HEp2 cells at a dilution of $1: 3$. Two volumes of $1: 4$ suspension of washed, insoluble aggregated gamma globulin were added to three volumes of serum and kept at $4^{\circ} \mathrm{C}$. overnight. The deposit was removed by centrifugation and the supernatant, a serum dilution of $1: 5$, tested in the fluorescent antibody technique.

INFECTED CELLS

Herpes simplex virus, measles virus, and mumps virus were grown in HEp2 cells, and rubella virus in BHK21 cells. The staining pattern of each virus is characteristic and easily distinguishable from the other three.

FLUORESCENT ANTIBODY STAINING

Virus-specific IgG and IgM were detected and titrated by indirect immunofluorescence by the method of Haire and Hadden (1970); that is, application of dilutions of patients' serum to virus-infected cells fixed on coverslips, which were then washed and exposed to fluorescein-conjugated anti-human IgG and conjugated anti-human IgM (Wellcome Reagents Ltd.). Sera were fully tested for specificity (Chantler and Haire, 1972). Staining by conjugated anti-IgG is called Igr staining; staining by anti-IgM is called IgM staining.

TESTING RHEUMATOID FACTOR

To test its effect on fluorescent staining, rheumatoid factor was applied directly to fixed cells or to fixed cells that had been treated with virus-specific IgG or it was mixed with human serum of known antibody content and held at $37^{\circ} \mathrm{C}$. for $1 \mathrm{hr}$ before the mixture was applied to fixed cells. Conjugated anti-IgG or anti-IgM was then applied. All sera and rheumatoid factors were fully absorbed with mouse liver powder and appropriate cultured cells before use. Suitable positive and negative controls were included in every experiment.

Table I Age distribution of patients with virus infections

\begin{tabular}{|c|c|c|c|c|c|c|c|c|}
\hline \multirow[t]{2}{*}{ Infection } & \multirow[t]{2}{*}{ Total } & \multicolumn{7}{|c|}{ Number of sera at years of age } \\
\hline & & $0-3$ & $4-8$ & $9-13$ & 14-18 & 19-23 & $24-28$ & $30+$ \\
\hline $\begin{array}{l}\text { Measles } \\
\text { Mumps } \\
\text { Rubella } \\
\text { Herpes simplex }\end{array}$ & $\begin{array}{l}6 \\
9 \\
8 \\
4\end{array}$ & $\begin{array}{l}0 \\
0 \\
0 \\
1\end{array}$ & $\begin{array}{l}4 \\
6 \\
0 \\
1\end{array}$ & $\begin{array}{l}0 \\
2 \\
0 \\
0\end{array}$ & $\begin{array}{l}1 \\
0 \\
4 \\
0\end{array}$ & $\begin{array}{l}1 \\
0 \\
2 \\
1\end{array}$ & $\begin{array}{l}0 \\
0 \\
1 \\
0\end{array}$ & $\begin{array}{l}0 \\
1 \\
1 \\
1\end{array}$ \\
\hline
\end{tabular}




\section{Results}

(1) Rheumatoid sera with and without rheumatoid factor

Since rheumatoid factor is known to contain much 19S globulin (Franklin, Holman, Müller-Eberhard, and Kunkel, 1957) and since it combines preferentially with antigen-bound IgG (Goodman, 1961), four rheumatoid sera, all containing rheumatoid factor, were tested for IgG staining and IgM staining of virus-infected cells, as we have defined this under Methods. Tests were compared before removing rheumatoid factor and after absorbing it from the sera, concentrations being adjusted before staining. The combined results appear in Table II, where it is shown that an individual serum may produce staining against all four or several of four viruses and that the IgM staining is removed by absorption of rheumatoid factor but IgG staining is not.

Table II IgG and IgM staining of virus antigen by 4 rheumatoid sera before and after removal of rheumatoid factor $(R F)$

\begin{tabular}{|c|c|c|c|c|}
\hline \multirow[t]{3}{*}{ Virus antigen } & \multicolumn{4}{|c|}{ Number of sera 'positive' } \\
\hline & \multicolumn{2}{|c|}{$\begin{array}{l}\text { Before removal of } \\
R F\end{array}$} & \multicolumn{2}{|c|}{$\begin{array}{l}\text { After removal of } \\
R F\end{array}$} \\
\hline & $\begin{array}{l}\text { IgG } \\
\text { stain }\end{array}$ & $\begin{array}{l}\text { IgM } \\
\text { stain }\end{array}$ & $\underset{\text { stain }}{\operatorname{Ig} G}$ & $\begin{array}{l}\text { IgM } \\
\text { stain }\end{array}$ \\
\hline $\begin{array}{l}\text { Measles } \\
\text { Mumps } \\
\text { Rubella } \\
\text { Herpes simplex }\end{array}$ & $\begin{array}{l}3 \\
2 \\
4 \\
4\end{array}$ & $\begin{array}{l}3^{*} \\
2^{*} \\
4 \\
4\end{array}$ & $\begin{array}{l}3 \\
2 \\
4 \\
4\end{array}$ & $\begin{array}{l}0 \\
0 \\
0 \\
0\end{array}$ \\
\hline
\end{tabular}

* The same individual sera as have IgG staining.

(2) Rheumatoid factor and virus-specific IgG

In a reconstruction experiment, semi-purified rheumatoid factor, which itself did not cause IgM staining of the four viruses, was used mixed in equal volume with pairs of sera, one serum being known to have virus-specific IgG, and the other having none. Application of the mixtures to virus-infected cells, followed by staining for IgG and IgM, gave the results seen in Table III. For all four viruses, rheumatoid factor in the presence of virus-specific IgG gives IgM staining of that virus; in the absence of virusspecific IgG, there is no such effect.

Application of a patient's serum to infected cells, followed by application of rheumatoid factor, gives the same result as applying a mixture of each. Sixteen more sera containing virus-specific IgG, four for each virus, failed to give IgM staining until rheumatoid factor was added; then IgM staining of virus antigen was produced by all.

(3) IgM staining by sera from virus infections

Rheumatoid factor or rheumatoid factor-like substance has been observed in sera from acute and
Table III Virus-specific IgM staining produced by the addition of rheumatoid factor $(R F)$ to serum

\begin{tabular}{|c|c|c|c|}
\hline \multirow[t]{2}{*}{ Antigen } & \multirow{2}{*}{$\begin{array}{l}\text { Serum } \\
\text { virus-specific } \\
\text { IgG }\end{array}$} & \multicolumn{2}{|c|}{ IgM staining } \\
\hline & & $\begin{array}{l}\text { Before } \\
\text { adding } R F\end{array}$ & $\begin{array}{l}\text { After } \\
\text { adding } R F\end{array}$ \\
\hline Measles & $\begin{array}{l}\text { Present } \\
\text { Absent }\end{array}$ & $\begin{array}{l}0 \\
0\end{array}$ & $\stackrel{+}{0}$ \\
\hline Mumps & $\begin{array}{l}\text { Present } \\
\text { Absent }\end{array}$ & $\begin{array}{l}0 \\
0\end{array}$ & $\begin{array}{l}+ \\
0\end{array}$ \\
\hline Rubella & $\begin{array}{l}\text { Present } \\
\text { Absent }\end{array}$ & $\begin{array}{l}0 \\
0\end{array}$ & $\stackrel{+}{0}$ \\
\hline Herpes simplex & $\begin{array}{l}\text { Present } \\
\text { Absent }\end{array}$ & $\begin{array}{l}0 \\
0\end{array}$ & $\begin{array}{l}+ \\
0\end{array}$ \\
\hline
\end{tabular}

from chronic infections (Bartfeld, 1960, 1969). We therefore examined sera taken from patients in the acute and then in the convalescent stages of measles, mumps, rubella, and herpes simplex infection and found a variable incidence of positive reactions to the latex-globulin test. A few reactions were strong at a dilution of $1: 5$, but most were weakly agglutinating (Table IV).

Table IV The presence of rheumatoid factor paired sera from virus diseases

\begin{tabular}{|c|c|c|c|}
\hline \multirow[t]{2}{*}{ Antigen } & \multirow{2}{*}{$\begin{array}{l}\text { Number of } \\
\text { patients }\end{array}$} & \multicolumn{2}{|c|}{ Number of agglutinating sera } \\
\hline & & Acute phase & $\begin{array}{l}\text { Convalescent } \\
\text { phase }\end{array}$ \\
\hline $\begin{array}{l}\text { Measles } \\
\text { Mumps } \\
\text { Rubella } \\
\text { Herpes simplex }\end{array}$ & $\begin{array}{l}7 \\
9 \\
8 \\
5\end{array}$ & $\begin{array}{l}1 \text { (strong) } \\
8 \text { (1* strong) } \\
3 \\
1 \text { (strong) }\end{array}$ & $\begin{array}{l}1 \text { (strong) } \\
8 \text { (1* strong) } \\
2 \\
1\end{array}$ \\
\hline
\end{tabular}

* The same patient's serum.

These sera were tested for IgM staining against the four virus antigens; one portion of serum unabsorbed and one portion absorbed with aggregated gamma globulin so that all latex-globulin agglutinin that had been present was removed. There were two differences between IgM staining by rheumatoid sera and IgM staining by sera from virus infection. Firstly, IgM staining by sera from infections was confined to the causative agent, that is, it was specific, whereas rheumatoid sera produced IgM staining of two or more viruses. Secondly, as seen in Table V, with the exception of two weakly-staining sera, virus-specific IgM staining in acute and convalescent sera was not removed by absorption with aggregated gamma globulin. The brightness of fluorescence produced by one or two sera was reduced after absorption of hreumatoid factor, but mostly contrast seemed to be 
Table V Virus-specific IgM staining in acute and convalescent sera before and after removal of rheumatoid factor by aggregated gamma globulin

\begin{tabular}{|c|c|c|c|c|}
\hline \multirow[t]{3}{*}{ Antigen } & \multicolumn{4}{|c|}{ No. of patients IgM positive } \\
\hline & \multicolumn{2}{|l|}{ Acute } & \multicolumn{2}{|l|}{ Convalescent } \\
\hline & Before absorption & After absorption & Before absorption & After absorption \\
\hline $\begin{array}{l}\text { Measles } \\
\text { Mumps } \\
\text { Rubella } \\
\text { Herpes simplex }\end{array}$ & $\begin{array}{l}6 \\
9 \\
8 \\
5\end{array}$ & $\begin{array}{l}6 \\
8 \\
8 \\
5\end{array}$ & $\begin{array}{l}3 \\
8 \\
8 \\
5\end{array}$ & $\begin{array}{l}3 \\
7 \\
7 \\
5\end{array}$ \\
\hline Total & 28 & 27 & 24 & 22 \\
\hline
\end{tabular}

better and brightness apparently increased after the treatment of the patient's serum with aggregated gamma globulin. A third observation, not relevant to the virus-specific IgM, was membrane staining of uninfected cells, seen particularly after the application of mumps convalescent sera and pointed out to us by Dr. Margaret Haire as being very like that produced by sera from patients having multiple sclerosis (Millar, Fraser, Haire, Connolly, Shirodaria, and Hadden, 1971). We do not know if it is related to the production of rheumatoid factor.

Because of the slight variation in these last findings, the titre of IgM staining by a few sera was estimated before and after absorption by aggregated human gamma globulin (Table VI). Two sera with relatively high rheumatoid factor titres showed a significant drop in titre of $\operatorname{IgM}$ after one absorption with aggregated globulin; the remainder did not. Second absorptions did not further reduce the IgM staining of any serum.

\section{Discussion}

Two kinds of virus-specific IgM staining have been revealed by our experiments. One is secondary to the presence of virus-specific IgG and is clearly due to the attachment of rheumatoid factor or like substances in the patients' serum. Their antiglobulin activity is indicated by their removal by aggregated human IgG and their composition is seen to be $\operatorname{IgM}$ in the fluorescent antibody reaction. The findings conform with the interference which has been shown by rheumatoid factor in many serological reactions (Heimer, Levin, Primach, Corcos, and Nosenzo, 1962; Heimer, Levin, and Kahn, 1963; Zvaifler and Bloch, 1962) including the fluorescent antibody test (Holborow and Johnson, 1965) and complementfixation by viruses (Stanford, 1972). Absorption of rheumatoid factor from a serum has also been shown to remove a factor producing nuclear staining (McCormick and Day, 1963), but we think our report

Table VI Titres of rheumatoid factor $(R F)$ and virus-specific IgM and IgG in the sera of patients with acute viral diseases before and after removal of rheumatoid factor

\begin{tabular}{|c|c|c|c|c|c|c|c|}
\hline \multirow[t]{2}{*}{ Antigen } & \multirow[t]{2}{*}{ Phase } & \multicolumn{2}{|l|}{$R F$} & \multicolumn{2}{|l|}{$\operatorname{Ig} M$} & \multicolumn{2}{|l|}{$I g G$} \\
\hline & & Before & After & Before & After & Before & After \\
\hline \multirow[t]{2}{*}{$\begin{array}{l}\text { Measles } \\
\text { ( } 2 \text { patients) }\end{array}$} & $\begin{array}{l}\text { Acute } \\
\text { Convalescent }\end{array}$ & $\begin{array}{l}80 \\
40\end{array}$ & $\begin{array}{l}0 \\
0\end{array}$ & $\begin{array}{l}40 \\
80\end{array}$ & $\begin{array}{l}10 \\
40\end{array}$ & $\begin{array}{r}80 \\
>80\end{array}$ & $\begin{array}{r}80 \\
>80\end{array}$ \\
\hline & $\begin{array}{l}\text { Acute } \\
\text { Convalescent }\end{array}$ & $\begin{array}{l}0 \\
0\end{array}$ & $\begin{array}{l}0 \\
0\end{array}$ & $\begin{array}{l}80 \\
80\end{array}$ & $\begin{array}{l}80 \\
80\end{array}$ & $\begin{array}{r}40 \\
>80\end{array}$ & $\begin{array}{r}40 \\
>80\end{array}$ \\
\hline \multirow[t]{2}{*}{$\begin{array}{l}\text { Mumps } \\
\text { (2 patients) }\end{array}$} & $\begin{array}{l}\text { Acute } \\
\text { Convalescent }\end{array}$ & $\begin{array}{r}10 \\
5\end{array}$ & $\begin{array}{l}0 \\
0\end{array}$ & $\begin{array}{l}80 \\
80\end{array}$ & $\begin{array}{l}80 \\
80\end{array}$ & $\begin{array}{r}80 \\
>80\end{array}$ & $\begin{array}{r}80 \\
>80\end{array}$ \\
\hline & $\begin{array}{l}\text { Acute } \\
\text { Convalescent }\end{array}$ & $\begin{array}{l}20 \\
20\end{array}$ & $\begin{array}{l}0 \\
0\end{array}$ & $\begin{array}{l}80 \\
80\end{array}$ & $\begin{array}{l}40 \\
80\end{array}$ & $\begin{array}{r}80 \\
>80\end{array}$ & $\begin{array}{r}80 \\
>80\end{array}$ \\
\hline $\begin{array}{l}\text { Rubella } \\
\text { (1 patient) }\end{array}$ & $\begin{array}{l}\text { Acute } \\
\text { Convalescent }\end{array}$ & $\begin{array}{l}5 \\
5\end{array}$ & $\begin{array}{l}0 \\
0\end{array}$ & $\begin{array}{l}20 \\
10\end{array}$ & $\begin{array}{l}20 \\
10\end{array}$ & $\begin{array}{r}10 \\
>40\end{array}$ & $\begin{array}{r}10 \\
>40\end{array}$ \\
\hline \multirow[t]{2}{*}{$\begin{array}{l}\text { Herpes simplex } \\
\text { ( } 2 \text { patients) }\end{array}$} & $\begin{array}{l}\text { Acute } \\
\text { Convalescent }\end{array}$ & $\begin{array}{r}20 \\
5\end{array}$ & $\begin{array}{l}\mathbf{0} \\
\mathbf{0}\end{array}$ & $\begin{array}{l}80 \\
80\end{array}$ & $\begin{array}{l}20 \\
80\end{array}$ & $\begin{array}{l}>80 \\
>80\end{array}$ & $\begin{array}{l}>80 \\
>80\end{array}$ \\
\hline & $\begin{array}{l}\text { Acute } \\
\text { Convalescent }\end{array}$ & $\begin{array}{l}\mathbf{0} \\
\mathbf{0}\end{array}$ & $\begin{array}{l}\mathbf{0} \\
\mathbf{0}\end{array}$ & $\begin{array}{l}10 \\
20\end{array}$ & $\begin{array}{r}5 \\
20\end{array}$ & $\begin{array}{l}>80 \\
>80\end{array}$ & $\begin{array}{l}>80 \\
>80\end{array}$ \\
\hline
\end{tabular}


is the first instance of rheumatoid factor regularly giving a misleading fluorescent antibody reaction. We have chosen to use the terms primary IgM staining and secondary IgM staining because the term nonspecific is incorrect both in respect of the anti-IgM conjugate and also with regard to the virus-specific IgG to which rheumatoid factor adheres. Moreover, non-specific staining is a term often used to mean nonimmunological in the fluorescent antibody test.

The virus-specific IgM staining which is not removable from serum by aggregated IgG is presumed to be a primary union between virus antigen and specific IgM. Other antiglobulins are known besides rheumatoid factor, but they are usually IgG in constitution not IgM (Waller, 1967) and so would not react with anti-IgM conjugate in the fluorescent antibody test. It should be noted that absorption or neutralization of a serum by specific virus would remove both primary and secondary IgM staining, for the latter depends on the presence of IgG which absorption with virus would remove.

The observations are important in surveying human sera for virus-specific IgM, and therefore, in correlating the various classes of virus-specific circulating antibody with persistent virus infections.

We have noted elsewhere (Fraser, Shirodaria, and Stanford, 1971) that some human sera which have no latex-globulin agglutinating power produce IgM staining of virus antigen which is also removed by absorption of the serum with aggregated human gamma globulin. Some of these were shown to contain rheumatoid factor in the euglobulin fraction of the serum (Stanford, unpublished, 1972). We therefore suggest that, in surveying sera for virus-specific IgM by the fluorescent antibody method, preliminary absorption with aggregated gamma globulin is an essential step. Concurrent testing of sera for rheumatoid factor, without absorption, is an inadequate precaution.

\section{Summary}

Some rheumatoid sera and some sera from acute virus infections produce IgM-specific immunofluorescent staining of virus antigens by the indirect fluorescent antibody technique. Our experiments show that such staining by rheumatoid sera is secondary and non-specific and is due to the adsorption of rheumatoid factor to complexes of virus and specific IgG. The IgM staining in acute virus infections is primary, virus-specific, and not due to rheumatoid factor. Any rheumatoid factor present in such sera has merely an enhancing effect on the virusspecific IgM staining.

We are particularly indebted to Dr. M. Haire and Dr. J. H Connolly for sera of known specificity towards viruses and to physicians at Musgrave Park Hospital and the Roya Victoria Hospital, Belfast, for sera from their patients.

This work was supported by a grant from the Arthritis and Rheumatism Council.

\section{References}

BARTFeld, H. (1960) Ann. intern. Med., 52, 1059 (Incidence and significance of sero-positive tests for rheumatoid factor in non-rheumatoid diseases)

(1969) Ann. N.Y. Acad. Sci., 168, Art. 1, 30 (Distribution of rheumatoid factor activity in non-rheumatoid states)

Baublis, J. V., And Brown, G. C. (1968) Proc. Soc. exp. Biol. (N.Y.), 128, 206 (Specific response of the immunoglobulins to rubella infection)

ChANTLER, S. AND HAIRe, M. (1972) Immunology, 23, 7 (Evaluation of the immunological specificity of fluoresceinlabelled anti-human IgM conjugates)

ConNolly, J. H., HAIRE, M., AND HADDEN, D. S. M. (1971) Brit. med. J., 1, 23 (Measles immunoglobulins in subacute sclerosing panencephalitis)

Franklin, E. C., Holman, H. R., Müller-Eberhard, H. J., and Kunkel, H. G. (1957) J. exp. Med., 105, 425 (An unusual protein component of high molecular weight in the serum of certain patients with rheumatoid arthritis)

Fraser, K. B., Shirodaria, P. V., and Stanford, C. F. (1971) Brit. med. J., 3, 707 (Fluorescent staining and human IgM)

Goodman, J. W. (1961) Proc. Soc. exp. Biol. (N.Y.), 106, 822 (Reaction of rheumatoid sera with fragments of papain-digested rabbit gamma globulin)

HAIRE, M., AND HADDEN, D. S. M. (1970) Brit. med. J., 3, 130 (Immunoglobulin responses in rubella and its complications)

Heimer, R., LeVIN, F. M., AND KahN, M. F. (1963) J. Immunol., 91, 866 (Inhibition of complement fixation by human serum. II. The activity of a $\gamma_{1} \mathbf{M}$ globulin and rheumatoid factor in complement fixation reactions)

- - _ - Primack, A., Corcos, J. M., AND Nosenzo, C, (1962) Ibid., 89, 382 (Inhibition of complement fixation by human serum)

Holborow, E. J., AND Johnson, G. D. (1965) Ann. N.Y. Acad. Sci., 124, Part 2, 833 (The nature of antinuclear immunoglobulins)

Millar, J. H. D., Fraser, K. B., Haire, M., Connolly, J. H., Shirodaria, P. V., and Hadden, D. S. M. (1971) Brit. med.J., 2, 378 (Immunoglobulin M specific for measles and mumps in multiple sclerosis) 
MCCORMICK, J. N., AND DAY, J. (1963) Lancet, 2, 554 (The association of rheumatoid factor with anti-nuclear factor activity)

SCHLUEDERBERG, A. (1965) Nature (London.), 205, 1232 (Immune globulins in human viral infections)

StANFoRd, F. (1972) Ann. rheum. Dis., 31, 330 (A comparison of complement-fixing antibody titres between patients with rheumatoid arthritis and matched controls)

WALLER, M., (1967) Immunology, 13, 623 (The relationship between rheumatoid factors and serum agglutinators)

Zvaifler, N. J., AND BlOCH, K. J. (1962) Arthr. and Rheum., 5, 127 (Rheumatoid factor: An inhibitor of the complement fixation reaction) 